\title{
The Nexus Between Microfinance \& Sustainable Development: Examining The Regulatory Changes Needed For Its Efficient Implementation.
}

\author{
Apoorva Ramaswamy* and Aditya Krishnamoorthy*
}

\begin{abstract}
Micro-Finance as a concept has been largely hit or miss in it's implementation. While Mohammed Yousuf helped launch the concept into the mainstream in the early 2000's, the use of Microfinance as a means of achieving Sustainable Development has gained traction only in recent years.

The aim of this paper is to analyze the regulatory changes which are required in order to ensure that Microfinance Institutions function efficiently, in order to contribute to Sustainable Development in India.

Through the course of this paper, the authors will examine a variety of Microfinance models in order, to comprehend their impact on Sustainable Development.

For this purpose, the authors will conduct quantitative and qualitative analysis of various stakeholders in the field of Microfinance and examine a number of successful Microfinance models from other developing nations, to assess the various challenges and issues faced by these institutions. Through the outcome of this analysis, the authors will seek to understand the regulatory status quo \& the lacunae prevailing in the law and will thereby seek to arrive at solutions, in order to successfully implement Microfinance as a means to Sustainable Development in India.
\end{abstract}

Key Words: Microfinance, Sustainable, Development, Regulation, India, Qualitative, Stakeholder

\section{Introduction}

For centuries, Microfinance Institutions, from the European Credit Union movement of the $19^{\text {th }}$ Century to the Microcredit movement propounded by visionaries such as Muhammad Yunus and Al Whittaker, have existed as a means to empower and provide opportunities to low-income communities. Over the years, the focus of these Microfinance Institutions has shifted from just Poverty Alleviation, to dealing with issues of sustainability. The entire ambit of Microfinance now encompasses both social and environmental factors, and these institutions have proven to be powerful tools in aiding Sustainable Development.

The term "Microfinance" in its most commonly understood form means, the provision of regular banking and financial services, such as credit and savings, to low-income communities who may not have been able to avail these services regularly. The modern use of the expression "microfinancing" is largely drawn from the example of the revolutionary Grameen Bank, founded by Muhammad Yunus, in the 1970's.

While the primary objective of Microfinance has largely been 'economic', in recent years 
the focus has shifted to a more 'social or developmental' objective.' Apart from these traditional aims, microfinance experts now argue that a third environmental' objective has come to the fore. "Green Microfinance" seeks to address these objectives, by providing low or moderate income individuals with loans and technical assistance, to help them procure and set up "green" or environmentally friendly products and technology. Microenterprises have been very popular in Asia, with the Asian Developmental Bank stating that they account for more than 60 per cent all enterprises and 50 per cent of paid employment ${ }^{3}$.

"Green Microfinance" can help reduce problems such as poverty and financial exclusion, while at the same time promoting environmental protection and energy efficiency. The impact of Microfinance on the environment could potentially be massive, largely because of the growing number of individuals who avail loans through MFI's. According to the IFC $^{4}$, an estimated 130 Million people use Microfinance around the globe, which is still only 20 per cent of its potential market. The emergence of many new "green" and environmentally friendly enterprises through Microfinance will have a major impact in slowing down environmental degradation.

Furthermore, most low-income groups, who avail Microfinance, are largely dependent on the use of natural resources, which speeds up their depletion. Using "Green Microfinance", these low-income groups can ensure that this depletion is substantially reduced, and that their businesses become sustainable. Thus, from the above, it becomes apparent that "Green Microfinance" presents numerous advantages to both the MFI's themselves, as well as to their clients and humanity as a whole,

The concept of "Green Microfinance", while relatively nascent in India, has been implemented with great success in the neighbouring Bangladesh. Grameen Shakti, an MFI in Bangladesh, has used microcredit to provide solar energy to hundreds of thousands of houses in rural Bangladesh ${ }^{5}$. A similar program in Guatemala called Genesis, uses microcredit through subsidies to support environmentally friendly production techniques in agriculture, for coffee and cocoa production farmers. A study conducted by the Natural Resources Institute [1], analysed a "green" microenterprise development program in Bangladesh, launched under the Building Environment Governance Capacity in Bangladesh (BEGCB) project. The authors of the study found that the microcredit programs, not only generated profits, but also presented numerous environmental benefits, such as health preservation, natural resource conservation etc.

1 Copestake, J. (2007) 'Mainstreaming Microfinance: Social Performance Management or Mission Drift?' World Development 35(10)

2 Hall, J, Collins, L., Israel, E. \& Wenner, M. (2008) 'The missing bottom line: Microfinance and the Environment'. Philadelphia: GreenMicrofinance-LLC

3 Asian Development Bank. Microenterprise Development: Not by Credit Alone. Asian

Development Bank (ADB), Manila, 1997. Available online: http://www.adb.org/Documents/

Books/Microenterprise/microenterprise.pdf (accessed on 23rd May 2016).

4IFC webpage,

http://www.ifc.org/wps/wcm/connect/Industry_EXT_Content/IFC_External_Corporate_Site/Industries /Financial+Markets/MSME+Finance/Microfinance/(accessed on 23rd May 2016)

5 Komatsu, S., Kaneko, S. \& Ghosh, P. (2011) 'Are micro-benefits negligible? The implications of the rapid expansion of Solar Home Systems (SHS) in rural Bangladesh for sustainable development'. Energy policy 39(7): 4022-4031 
The above programs are indicative of the fact that MFI's can certainly benefit environmental development in developing nations. The authors, through a "case study" conducted on 2 MFI's in India, namely the URJA Project of the SEWA Bank and ESAF Microfinance, will aim to understand the current scenario regarding "green microfinance" in India, with regards to Investment, Client base, Revenue, Feasibility etc. and thereby assess the regulatory changes required to make "Green Microfinance" a sustainable.

\section{Case Studies:}

Having established that there have been examples of green microfinance institutions in other countries which have been successful in following the triple bottom approach, this chapter aims at examining some of the Indian models for green microfinance. The institutions which have been selected are Project URJA, an initiative by the SEWA Bank and EHAS Microfinance. These models have been selected for the following reasons: Limited availability of data on other microfinance institutions, relative ease of comparison as their environmental policy/loans are geared towards the same sector that is the energy sector.

At the end of this chapter, we have also attempted a case study of a green microfinance institution from another developing country that is Grameen Shakti from Bangladesh, in order to arrive at an understanding of the differences in working, limitations if any which can be overcome in the Indian models and improvements which can be made for a more efficient system.

\subsection{Project URJA}

Project URJA was initiated by the SEWA Bank in the year 2006 in order to improve SEWA members access to energy services. This project was the result of a study commissioned by the United Nations Office for Project Services, jointly undertaken by SEWA Bank and MHT (Mahila Housing Trust) to develop a consumer lending and micro finance strategy to expand access to energy services for the rural and urban poor. ${ }^{6}$ This project relies on funding from the SEWA Bank and MHT and technological assistance from the SELCO foundation to provide its members with renewable, reliable and affordable energy. The SEWA Bank not being registered under the Foreign Contribution Registration Act, funds for the energy programme are routed through the MHT from the Lemelson Foundation and from the United Nations Office for Project Services (UNOPS). While the funds from UNOPS were used for conducting the need assessment survey, the funds from the former were used in the course of the project to fund the entrepreneurs and for capacity building. ${ }^{7}$

6 The following discussion of URJA Project is heavily based on the following source, Richard D Hansen. (2007). Yale University School of Management website. Retrieved 5 May, 2016, from http://nexus.som.yale.edu/design-selco/?q=node/121

7 Hilman, Gidwani, Morris, Subedi, \& Chowdhary. (2007). microfinance gateway. Retrieved 7th May, 2016, from http://www.microfinancegateway.org/library/using-microfinance-expand-access-energyservices-emerging-experiences-asia-self-employed. 


\subsubsection{Environmental policy or objectives as set out for defining the institution's approach towards green microfinance:}

After conducting a need assessment survey, it was found that a significant amount of time and money was being used up for the collection of firewood which apart from the financial burden was also posing significant health risks to households. The key aim behind this project was to reduce drudgery by increasing time availability and income generating capacity of its members and introduce more cleaner and efficient forms of energy in the form of biogas and solar energy. Another aim is that of empowering women through technology. This contributes indirectly to the environment though not explicitly an environmental objective. Use of technology in a way so as to reduce time and energy in the care economy makes them available for participation in the local economy thereby reducing poverty and improving status of women in their local communities at the social, economic and political level. This is critical as poverty usually goes hand-in hand with environmental degradation 8 and empowerment of women contributes or is rather a significant aspect of sustainable development. 9

\subsubsection{The procedure involved in setting up such green microfinance institutions or the process for implementing green principles by existing institutions:}

As already discussed an extensive need assessment survey was carried out amongst the various cooperatives in order to in order to identify specific areas in the energy requiring intervention. ${ }^{10}$ After the said study reaffirmed the intention of the study, URJA was established in 2006. Further four Focus Discussion Groups were held by MHT and SEWA Bank. The meetings resulted in the detection of an immediate need in certain areas as well as a need to raise awareness about the availability of improved access to energy with a financing mechanism to overcome the first cost barrier. ${ }^{11}$

\subsubsection{The environmental services/products rendered:}

An important aspect of the project is the partnership between SEWA and SELCO. While SEWA is responsible for financing the project, it benefits from the technological assistance provided by SELCO as its clients can avail of customized products to suit their needs without bearing the burden of any technical risk. On the other hand, SELCO gains from SEWA Bank's huge client base of 290,000 and existing infrastructure, which reduces its transaction costs. ${ }^{12}$

The survey conducted revealed that help was required the most in two main areas of lighting and cooking for which the project offers solar home light, solar lantern, Improved Smokeless Stove and Sarai Cooker all of which are customized courtesy

\footnotetext{
8 World Commission on Environment and Development, (1987), Our Common Future, Oxford University Press.

9 Warth, Koparanova. (2012). United Nations Economic Commission for Europe website. Retrieved 17th May, 2016, from https://www.unece.org/fileadmin/DAM/oes/disc papers/ECE DP 2012-1.pdf

10 Richard D Hansen. (2007). Yale University School of Management website. Retrieved 5 May, 2016, from http://nexus.som.yale.edu/design-selco/?q=node/121

${ }^{11} \mathrm{Ibid}$. Footnote no. 5.

12 Hilman, Gidwani, Morris, Subedi \& Chowdhary. (2007). microfinance gateway. Retrieved 7th May, 2016, from http://www.microfinancegateway.org/library/using-microfinance-expand-access-energyservices-emerging-experiences-asia-self-employed
} 
SELCO, to meet the needs of the individual member. Loans are offered for certain products (not all as some are low in cost and can be paid for in cash) at flexible repayment mechanism within the term of loan. There is also an interest subsidy of 7 percent offered on the energy loans (refunded on the timely completion of loan). ${ }^{13}$ The loan payment is directly made to SELCO, and the client is directly given the equipment. Other special features of this loan are as follows:

- A compulsory 15 day trial period in order to be satisfied as to the costumer's need for the product.

- $\quad$ Advice from the SELCO staff in order to buy the product which is the least costly and most efficient to fulfill their needs.

- User training for maintenance and operation at time of installation.

- $\quad$ Free after-sale service during the warranty period.

\subsubsection{The tools used for marketing and promotion:}

1. Establishment of an energy park at Manipur village, Ahmedabad to demonstrate the use of the various solar appliances and to train women in the installation and usage of the same.

2. Demonstration Unit at the main office of SEWA for display of the solar appliances under the project.

3. Demonstration programs at streets, houses and nearby areas for illustrating the use of some of the basic appliances.

4. Training programs for potential women entrepreneurs selected for training.

5. Amrud Jarnu van, a mobile van used to promote SEWA Bank's products.

6. URJA energy fairs held to spread awareness of the products offered under this project.

\section{ESAF Microfinance:}

ESAF Microfinance has set up a separate division devoted to environmental issues and is ranked highly in a study on the performance of Indian MFIs reporting social data to $\mathrm{MIX}^{14}$.

\subsection{Environmental policy or objectives as set out for defining the institution's approach towards green microfinance:}

ESAF has set up the Natural Resource Management (NRM) program with the goal of efficient management and conservation of the natural resources. It works in the following areas:

1. Non Conventional Energy and Green Conservancy projects.

2. Rural water supply and sanitation projects for Kerala Govt.

3. Engineering Services.

4. Micro Energy projects.

13 Ibid. Footnote no 7.

14 Themixorg. (2016). Themixorg. Retrieved 25 May, 2016, from http://www.themix.org/publications/mixmicrofinance-world/2014/08/India-development-findings-2014-second 
For the purposes of this paper, we are focusing on the micro-energy projects.

\subsubsection{The environmental services/products rendered:}

Provision of micro energy loans/ Suryajyothi loans for promoting clean energy products like solar lamps, energy efficient cooking stoves, water purifiers, etc.

\section{Grameen Shakti}

Grameen Shakti was established as a not for profit in 1996 in Bangladesh. It is the energy wing of the Grameen family of organizations. Since 1996 it has installed over $30 \mathrm{MW}$ of power, brought energy to over 4 million people, and sold nearly 900,000 energy products. ${ }^{15}$

\subsection{Environmental policy or objectives as set out for defining the institution's approach towards green microfinance:}

Over $48 \%$ of Bangladeshis, and $70 \%$ of rural Bangladeshis, lack access to the power and gas grids. Due to the country's poverty and the isolation of many communities, this is not a problem that centralized, government-built power sources, will be able to fix in the near future. ${ }^{16}$ Grameen Shakti was established with a view to empowering rural people with access to Green Energy and increasing income. Their vision for 2015 stands as follows ${ }^{17}$ :

\section{- $\quad 7.5$ million Solar Home Systems}

- 2 million Biogas Plants

- 20 million Improved Cooking Stoves

- $\quad 100,000$ Green Jobs especially for young women.

\subsection{The environmental services/products rendered:}

Grameen Shakti offers a range of solar home systems, from 10 to $135 \mathrm{~W}$, for offgrid consumers as well as improved cook stoves, biogas digesters and organic fertilizer. Unlike the case of URJA there is no technological partner. While the solar panels are imported mainly from Japan, the rest are sourced from local suppliers. GS is able to invest heavily in training for its field staff to develop their capacity to produce SHS( Solar home systems) accessories locally. The locally made accessories reduce costs of the renewable energy products. ${ }^{18}$ It now has 46 Grameen Technology Centers, across the country, managed by female engineers and staffed by female technicians assembling their solar components. These GTC's also train the end-users to operate the appliances in the correct manner. The products are sold by its own salesman. They are also 'social

\footnotetext{
15 Energymap-scuorg. (2016). Energymap-scuorg. Retrieved 4th May, 2016, from http://energymapscu.org/grameen-shakti/.

16 Ibid. Footnote no 10.

17 Energymap-scuorg. (2016). Energymap-scuorg. Retrieved 4th May, 2016, from http://energymapscu.org/grameen-shakti/.

18 K. R. (2012). Green microfinance promoting green enterprise development.International Journal of Research Studies in Management, 1(1), 85-96. doi:10.5861/ijrsm.2012.v1i1.32.
} 
engineers' appointed by the GS to perform demonstrations in each household and technicians to perform after sales service.

\subsection{The tools used for marketing and promotion:}

Grameen Shakti uses local community members to market its products, such as teachers and elected leaders. It also installs systems in public places to raise awareness. Grameen Shakti also hires and trains technicians from the communities in which it sells, and trains users to take care of their systems, thereby developing personal customer relationships which have helped with word of mouth sales ${ }^{19}$.

\section{Conclusions: Regular changes}

The above case studies are all examples of institutions wherein a green wing or operation was started sometime after the establishment of the parent institution. This could be interpreted as evidence consistent with the hypothesis advanced by Allet and Hudson (2013) on the characteristics of microfinance institutions involved in environmental management. They have concluded that the age is a determinant factor, with more mature microfinance institutions being more likely to offer green credit and environmental non-financial services ${ }^{20}$. We argue that this is detrimental as there are a burgeoning number of microfinance institutions and we cannot afford to ignore their impacts on the environment as being trivial. If we have to wait till they reach the point of maturity to offer environmental services then it could reduce the potential benefits or could in fact increase the negative impact on the environment. However, there are potential non-financial environmental services that micro-financial institutions can provide in their infancy without this being detrimental to their financial stability. It is not essential to be termed as green microfinance institution in order to provide financial support to green products or services. There are other viable options, some of these have been discussed by Abhishekh Lal (2015) in his paper "The missing bottom line: Microfinance and the Environment" 21 . These include providing environmental education and increasing awareness. This could be made a prerequisite to providing the loans and it could potentially work out well as it requires no extra expenditure on the part of the person availing the loan. The potential entrepreneurs could then spread this knowledge amongst their community members. Incentives in the form of better interest rates or a more flexible repayment schedule can be provided on the condition that they adhere to certain practices to benefit the environment.

Another method would be the inclusion of an Environment Impact Assessment Process (EIA) which can take two forms. One would be an EIA to assess the impact of the institution itself on the environment or another would be an EIA to assess whether a

\footnotetext{
19 Energymap-scuorg. (2016). Energymap-scuorg. Retrieved 4th May, 2016, from http://energymapscu.org/grameen-shakti/.

20Allet, M., \& Hudon, M. (2013). Green Microfinance: Characteristics of Microfinance Institutions Involved in Environmental Management. Journal of Business Ethics, 126(3), 395-414

21 Fabio Daneri (2015). Protecting The Environment: Green Microfinance Or Green Micro Finance Institutions? Academic Journal of Business, Administration, Law and Social Sciences, 1(1), 113-118.
} 
loan should be given to a potential client depending on the environmental impacts of the proposed project (depending on whether the potential benefits outweigh the potential environmental costs). A wider application of this concept would be the environmental screening which takes into account the environmental impact of the enterprise seeking the loan as a whole. This obviously is applicable only at the organizational level and not at the individual level. It has been pointed out by Fabio Daneri (2015) that these options also include operating costs. A solution for the same could take the form of funds for environmental protection from donors. This is an important component as seen in the case of the URJA Project which received grants from the Lemelson Foundation and UNOPS. In addition partnership with organizations working in the same sector to provide technological assistance etc., could help significantly in lowering the operating costs. For instance a Microfinance Institution lending loans for the purposes of building water canals, tanks, wells etc. can partner with Tarun Bhagat Sangh, an organization set up by Rajendra Singh ${ }^{22}$ which focuses on traditional methods for sustainable use and conservation of water. These options are not only viable but becoming an absolute necessity in times when environmental regulations are on the rise.

\section{References}

Copestake, J. (2007) 'Mainstreaming Microfinance: Social Performance Management or Mission Drift?' World Development 35(10)

Hilman, Gidwani, Morris, Subedi, \& Chowdhary. (2007). microfinance gateway. Retrieved 7th May, 2016, from http://www.microfinancegateway.org/library/using-microfinance-expand-accessenergy-services-emerging-experiences-asia-self-employed.

The following discussion of URJA Project is heavily based on the following source, Richard D Hansen. (2007). Yale University School of Management website. Retrieved 5 May, 2016, from http://nexus.som.yale.edu/design-selco/?q=node/121

Energymap-scuorg. (2016). Energymap-scuorg. Retrieved 4th May, 2016, from http://energymapscu.org/grameen-shakti/.

Fabio Daneri (2015). Protecting The Environment: Green Microfinance Or Green Micro Finance Institutions? Academic Journal of Business, Administration, Law and Social Sciences, 1(1), 113118.

22 http:/ / tarunbharatsangh.in/policy-level/ (accessed on 23 $3^{\text {rd }}$ May, 2016) 